\title{
THE ECONOMIC FRINGE: THE REACH OF THE ROMAN EMPIRE IN ROUGH CILICIA
}

By

HUGH W. ELTON

Many discussions of the Roman economy are rather vague about what they mean by 'Roman'. Phrases such as 'Roman Europe' or 'the Roman Empire' often blur two different concepts, that of the cultures of Iron Age Europe and the political institution of the Roman Empire. Cultures in Iron Age Europe varied widely. The Welsh uplands or the Atlas mountains, for example, had an aceramic culture with few public buildings, though were ruled directly by Rome for several centuries. Other regions, not under Roman control, like the regions across the middle Danube, showed higher concentrations of Mediterranean consumer goods and coins than some of these aceramic areas. ${ }^{1}$ In Mesopotamia, many societies were urban and literate, not differing in this respect from those in Italy or Greece. Thus, determining what was imperial Roman territory by archaeological criteria alone is very difficult. ${ }^{2}$ But these archaeological criteria are important for two reasons. First, they allow us to analyse the cultural and economic changes that occurred in Iron Age Europe between 100 B.C. and A.D. 250. Second, they allow for the possibility of change within Europe that was not caused by the Roman state. ${ }^{3}$

Unlike cultures within Iron Age Europe, the Roman Empire was a political structure, imposed by force and dedicated to extracting benefits for the ruling elite of the city of Rome. ${ }^{4}$ As the empire developed and matured, its form changed, but it was never about the ruled, only the rulers. If we accept that the Empire was a political, not an archaeological, structure, it follows that an examination of 'Impact of Empire: Transformation of Economic Life', has to mean an examination of the impact of the Roman imperial state. This paper has a regional focus, so does not deal with larger

\footnotetext{
' L. Pitts, 'Roman Style Buildings in Barbaricum (Moravia and SW Slovakia)', Oxford Journal of Archaeology 6 (1987), 219-236; cf. H.W. Elton, 'Defining Romans, Barbarians and the Roman Frontier', in R.W. Mathisen \& H.S. Sivan, eds., Shifting Frontiers in Late Antiquity (Aldershot 1996), 126-135. See the article of D.J. Mattingly in this volume.

2 D.J. Mattingly, ed., Dialogues in Roman Imperialism (Portsmouth, RI 1997); F. Millar, 'Introduction', in S. Macready \& F.H. Thompson, eds., Roman Architecture in the Greek World (London 1987), ix-xv at xi.

${ }^{3}$ R. Hingley, 'Resistance and Domination: social change in Roman Britain', in D.J. Mattingly, ed., Dialogues in Roman Imperialism (Portsmouth, RI 1997), 81-100 at 85 n.18.

${ }^{4} \mathrm{G}$. Woolf, 'Imperialism, Empire and the Integration of the Roman Economy', World Archaeology 23 (1992), $283-293$.
} 
elements of the Roman impact. Being in the Roman Empire did have an impact on regional economies. Roman control of the Mediterranean created a common market that allowed large-scale import and export of goods, especially low-cost commodities such as pottery, within a predictable framework of language, law and currency. But this common market was an unintended byproduct, and had more to do with being in an empire than being in the Roman Empire. ${ }^{5}$

The cultural and political impact of Rome can be measured by comparing a pre-Roman region to the region under Roman rule. Most scholarly literature, which discusses the changes between pre-Roman and Roman periods (a process of usually known as Romanization), has focused on the west, especially Gaul and Britain. ${ }^{6}$ Since this approach relies heavily on archaeological (including epigraphic) evidence, it tends to be more informative about Roman cultural than political impact. Many of these conclusions are valid only where Rome was the first empire in a region. This is often true in the west, but far less so in the east, where many other areas already had widespread exchange systems. ${ }^{7}$ Work on Romanization in the east is mostly recent. Much of this work is based on literary texts, especially those of the Second Sophistic, so tends to be cultural rather than political. ${ }^{8}$ In both east and west, some recent work has minimised the Roman impact on a region, but does so without discussing the political changes brought about by Rome. ${ }^{9}$

This paper applies a politically focussed analysis of the economic changes brought about by Roman imperial rule to one region of Asia Minor, Rough Cilicia. ${ }^{10}$ This region, approximately bounded by the river Melas in the west and the Lamus in the east, runs from the Mediterranean in the south to Lake Trogitis in the north. It was a region dominated by the Taurus mountains, with few aristocrats taking part in the imperial system and no major garrison.

\footnotetext{
${ }^{5}$ P.W.M. Freeman, 'Romanisation and Roman material culture', Journal of Roman Archaeology 6 (1993), 438-444.

${ }^{6}$ E.g. M. Millett, The Romanization of Britain (Cambridge 1990); G. Woolf, Becoming Roman: the origins of provincial civilisation in Gaul (Cambridge 1998).

${ }^{7}$ Z.H. Archibald, ed., Hellenistic Economies (London, 2000).

${ }^{8} \mathrm{G}$. Woolf, 'Becoming Roman, staying Greek: culture, identity and the civilising process in the Roman East', Proceedings of the Cambridge Philological Society 40 (1994), 116-143; S. Swain, Hellenism and Empire (Oxford 1996); S. Alcock, ed., The Early Roman Empire in the East (Oxford 1997); N. Pollard, Soldiers, Citizens and Civilians in Roman Syria (Ann Arbor 2000).

${ }^{9}$ W. Ball, Rome in the East (London 2000); J. Webster, 'Creolising the Roman provinces', American Journal of Archaeology 105 (2001), 209-225.

${ }^{10}$ T.B. Mitford, 'Roman Rough Cilicia', $A N R W$ II 7.2 (Berlin 1980), 1230-1261.
} 


\section{Rough Cilicia in the Early Roman Empire}

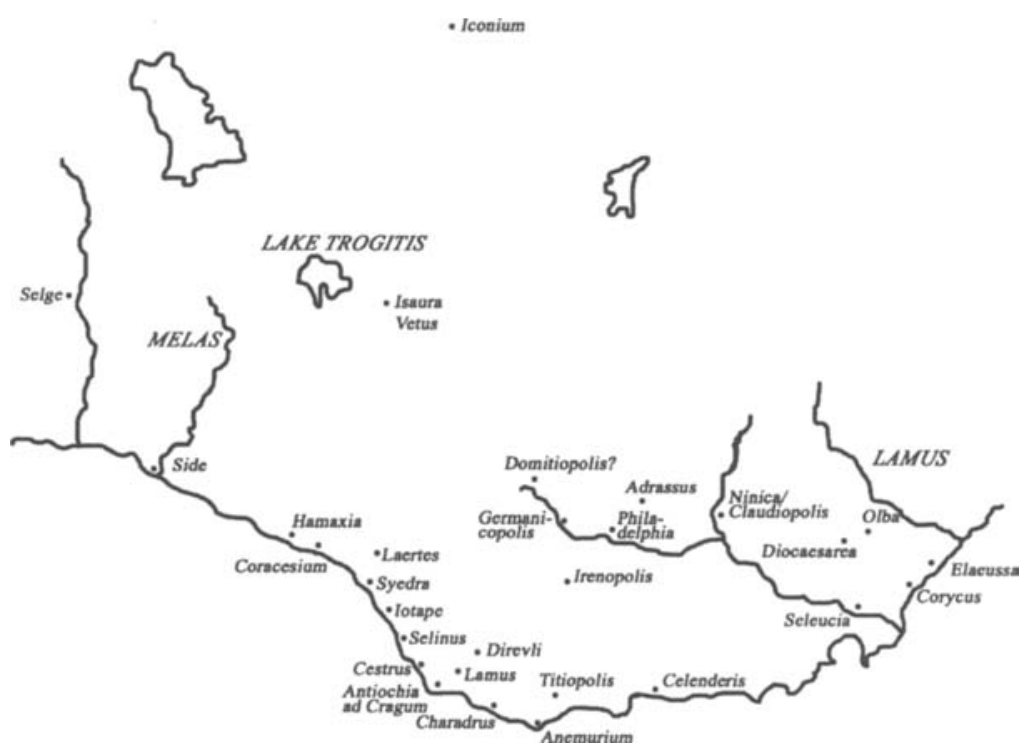

Imperial power in the eastern Taurus mountains was nothing new when Rome arrived. During the first millennium B.C., the region had been controlled by Assyrians and Achaemenid Persians, then the Greeks arrived, in several varieties - Alexander, the Seleucids and the Ptolemies, as well as a brief Armenian interlude. The imposition of Roman imperial authority by Pompey in 63 B.C. was simply the replacement of one imperial layer with another. ${ }^{11}$

This Roman imperial layer, however, was not simple. ${ }^{12}$ Although Pompey created a single province of Cilicia in 63 B.C., this was split into two parts in the mid-40s B.C. Lowland Cilicia was incorporated into the province of Syria, a situation which lasted until A.D. 72, while Rough Cilicia was left in the hands of allied kings. Strabo explained it as 'the Romans thought it was better for the region to be under kings rather than subject to

\footnotetext{
${ }^{11}$ P.W.M. Freeman, 'The Province of Cilicia and its Origins', in P.W.M. Freeman \& D.L. Kennedy, The Defence of the Roman and Byzantine East (Oxford 1986), 253-275.

${ }^{12}$ For primary references for the political changes in the region, D. Magie, Roman Rule in Asia Minor (Princeton 1950) and Mitford 1980, op. cit. (n.10).
} 
Roman governors who were sent out to administer justice, who were not going to be everywhere at once, nor with an armed force. ${ }^{, 13}$ There was no single ruler in the early days. In 39 B.C., Antony gave an inland Cilician kingdom (which included Iconium) to Polemo, and the coastal regions (including Coracesium and Hamaxia) to Cleopatra. In 37/6 Polemo was removed from his principality which was then added to the Galatian kingdom of Amyntas. The temple-state at Olba (whose territory included Elaeussa and Corycus) remained under native rulers. Seleucia on Calycadnus was probably a free city. ${ }^{14}$ After the battle of Actium (31 B.C.), Cleopatra's possessions along the coast were handed over to king Amyntas of Galatia who then ruled all of the region except Olba and Seleucia.

On Amyntas' death in 25 B.C., his Rough Cilician territories were divided into two parts. The western parts, from the Melas to Syedra, were included in the new province of Galatia, as was the Augustan colony of Ninica on the Calycadnus. ${ }^{15}$ The eastern parts were given to Archelaus I, king of Cappadocia (25 B.C. - A.D. 17). ${ }^{16}$ In 20 B.C. Augustus also gave Archelaus the cities of Elaeussa and Corycus (which had been either independent or part of the Olban principality). When Archelaus died in A.D. 17, his Cappadocian kingdom was annexed by Rome, but his son Archelaus II succeeded him in Rough Cilicia (17-38). On Archelaus II's death in 38, his kingdom was given to Antiochus IV of Commagene (38-72). In 41 Olba was given to Polemo II. ${ }^{17}$

Antiochus' kingdom of Commagene was taken over by the Romans in 72. A new province of Cilicia with its own governor was created. It combined lowland Cilicia, now detached from Syria, and the parts of Rough Cilicia that had been controlled by Antiochus. At this point, Polemo's Olba was perhaps transferred by Vespasian to Alexander, Antiochus' son-in-law. ${ }^{18}$

Although the detailed history is confusing, it shows that phrases such as 'the arrival of the Romans', 'the annexation of a province' or 'the imposition

\footnotetext{
${ }^{13}$ Strabo 14.5.6.

${ }^{14}$ Mitford 1980, op. cit. (n.10), $1241+$ n.45.

${ }^{15}$ Seleucia, in Galatia?, S. Mitchell, Anatolia I (Oxford 1993), 152.

${ }^{16}$ H.W. Elton, 'Geography, Romans, Labels and Cilicia', in H.W. Elton \& G. Reger, eds., Regionalism in Hellenistic and Roman Asia Minor (Ann Arbor, forthcoming).

${ }^{17}$ R.D. Sullivan, 'King Marcus Antonius Polemo', Numismatic Chronicle 19 (1979), 6-20 summarises a complex situation.

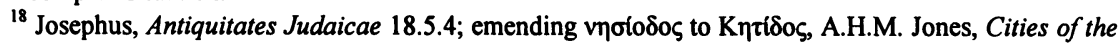
Eastern Roman Provinces (Oxford 1971, 2nd ed.), 195 f., $208+$ n.30; against, Mitford 1980, op. cit. (n.10), 1245; the precise location of Cetis is uncertain.
} 
of Roman authority' do not reflect the realities of this region. Before 72, Rough Cilician territories had been part of the Roman empire for over a century. They were ruled indirectly, but the rulers were appointed by Rome. The region was surrounded on all sides by directly ruled Roman territory, lowland Cilicia to the east, Cappadocia and Lycaonia to the north, Pisidia and Pamphylia to the west. This gave access to many of the benefits of the Roman common market, i.e. protection from enemies and access to goods sold by Roman traders. Thus they were Romanized though not imperial Roman citizens.

All rulers of the region, whether Hellenistic monarchs, Roman governors or allied kings, had the same concerns, collecting taxes and maintaining law and order. Power was exerted through cities. The more heavily Hellenized cities were in the western part of the region around Syedra and Iotape, extending along the coast as far as Antiochia ad Cragum. Inland, there are fewer traces of urban life and in the Calycadnus valley, Germanicopolis has left only five inscriptions, Claudiopolis 32 . The modern cities of Ermenek and Mut, which overlie Germanicopolis and Claudiopolis, have perhaps destroyed most ancient traces, but when compared with the meagre traces of other sites, like Irenopolis, Philadelphia or Adrassus where there is no modern development, both appear typical of inland Rough Cilician cities. Whether this means they were less developed, or were simply less prone to set up inscriptions is difficult to say. Nonetheless, it is critical, since most of our knowledge of communities in the region come from inscriptions. The epigraphic habit was primarily an urban response to the arrival of the Romans and there are far more Cilician inscriptions from the first two centuries of the Roman empire than there are from the Hellenistic period. There are very few Latin inscriptions in Rough Cilicia - a recent collection from the region lists 1977 inscriptions in Greek and only 32 in Latin. ${ }^{19}$

When the province of Cilicia was created in 72 , there were only three cities of any size (perhaps 5,000+) in Rough Cilicia, Seleucia, Claudiopolis and Germanicopolis. But over the preceding century, the urban landscape had changed with the creation of numerous cities. In the 30s B.C., the cities of Domitiopolis and Titiopolis were named after Lucius Domitius Ahenobarbus and Marcus Titius, supporters of Antony in the early 30s who

${ }^{19}$ S. Hagel \& K. Tomaschitz, Repertorium der westkilikischen Inschriften (Vienna 1998), 9. 
deserted to Octavian before 31 B.C. ${ }^{20}$ Soon after, an Augustan colony was founded at Ninica in the Calycadnus valley. ${ }^{21}$ The sanctuary of Zeus near Olba was turned into the city of Diocaesarea around this time. ${ }^{22}$ During the reign of Claudius, a number of south Galatian cities took Claudius' name; Ninica was one of these, and was known afterwards as Claudiopolis. ${ }^{23}$ The most prolific founder of cities in the regions, however, was Antiochus IV. $\mathrm{He}$ founded the coastal cities of Antiochia ad Cragum, named after himself, and Iotape, after his wife. He also founded the inland cities of Irenopolis, Philadelphia and Germanicopolis. ${ }^{24}$ This urban landscape was typical of the Greek east; cities had their own councils with gymnasiarchs, demiurges and eirenarchs. But the cities, especially the inland cities, were small and poor. However, we know of no equestrians or senators from Rough Cilicia. Since other upland areas along the southern coast, such as Lycia or Pisidia did produce senators and equestrians, this suggests that Rough Cilicia was exceptionally poor. ${ }^{25}$

The reason for the cities' small size and poverty was the lack of agricultural land throughout the region except in small coastal pockets and in the upper Calycadnus valley. These regions grew vines, olives and wheat, but the uplands were restricted to lesser crops, timber, saffron (particularly from Corycus), storax (for incense), and goat-hair, which was synonymous with the region. ${ }^{26}$ Given the limited carrying capacity of much of the land, many of the population had to find alternative means of subsistence. In the

${ }^{20}$ R. Syme, 'Isauria in Pliny', Anatolian Studies 36 (1986), 159-164 = Roman Papers 5, edited by A.R. Birley (Oxford 1988), 661-667 at $663 \mathrm{f}$.

${ }^{21}$ S. Mitchell, 'Iconium and Ninica', Historia 28 (1979), 409-438 superseding B. Levick, Roman Colonies in Southern Asia Minor (Oxford 1967), 198-199.

${ }^{22}$ R. Heberdey \& A. Wilhelm, Reisen in Kilikien, 1891 und 1892. Österreichische Akademie der Wissenschaften, Denkschriften 44 (Vienna 1896), \#160; E. Kirsten, 'Diokaisarea und Sebaste, Zwei Städtegründungen der fruhen Kaiserzeit im kilikischen Arbeitsgebiet der Akademie', Anzeiger der Österreichischen Akademie der Wissenschaften in Wien 110 (1973), 347-363.

${ }^{23}$ Mitchell 1979, op. cit (n.21), Augustan date at 430, n.138.

${ }^{24}$ Jones 1971, op cit. (n.18), 211 and n.36. Iuliosebaste may also be a new foundation, if it is not identified with Nephelis. See I. Karamut \& J. Russell, 'Nephelis: a recently discovered town of coastal Rough Cilicia', Journal of Roman Archaeology 12 (1999), 355-371 at 366-367.

${ }^{25}$ H. Devijver, 'Equestrian Officers from the East', in P.W.M. Freeman \& D.L. Kennedy, eds., Defence of the Roman and Byzantine East (Oxford 1986), 109-225; H. Halfmann, 'Die Senatoren aus den kleinasiatischen Provinzen des römischen Reiches vom 1. bis 3. Jahrhundert (Asia, Pontus-Bithynia, Lycia-Pamphylia, Galatia, Cappadocia, Cilicia)', Tituli 5 (1982), 603-650; H. Devijver, 'Local Elite, Equestrians and Senators. A Social History of Roman Sagalassos', Ancient Society 27 (1996), 105-162.

${ }^{26}$ T.R.S. Broughton, 'Roman Asia Minor', in T. Frank, ed., An Economic Survey of Ancient Rome 4 (New York 1938), 499-918; F. Hild \& H. Hellenkemper, Kilikien und Isaurien, Tabula Imperii Byzantini 5 (Vienna 1990) 1, 104-127. 
Hellenistic period, many Cilicians became soldiers, a practice continued in the Roman period. ${ }^{27}$ Another response was to turn to banditry, either on land or sea. ${ }^{28}$ These pressures also account for the frequent outbreaks of violence in the region. When Archelaus II wanted to carry out a census of the Cietae in 36, they took to the hills in revolt and had to be pacified by Roman forces sent from Syria. ${ }^{29}$ Other Roman interventions occurred in 4-3 B.C., A.D. 4348 and in $52 .{ }^{30}$

Despite these insecurities, there were no Roman garrisons in Rough Cilicia, either before or after $72 .{ }^{31}$ The economic impact of Roman garrisons is well-known; they required supplies of wheat, leather, olive oil, wine, alcohol, etc. Beyond the supplies themselves, there was also a need for carters, barrels and sacks, amphorae, plates and cups, etc. Around military bases, accommodation for merchants and suppliers led to the establishment of vici with taverns and brothels, which then brought their own demands. These impacts, well-understood in Gaul or Britain, were lacking in Rough Cilicia. $^{32}$

So, soldiers were recruited, taxes collected, cities were founded, governors administered, and occasionally built or repaired buildings. But all these things had happened before under Hellenistic rulers and in this respect, Roman direct rule meant little.

Nonetheless, there were some changes, which reflected actions of the Roman imperial power, in particular the imperial cult and communications. The foundation of the province of Cilicia in 72 was followed very quickly by

\footnotetext{
${ }^{27} \mathrm{~J}$. Russell, 'Cilicia - nutrix virorum: Cilicians abroad in peace and war during Hellenistic and Roman Times', De Anatolia Antiqua 1 (Paris 1991), 283-297; J. Russell, 'A Roman Military Diploma from Eastern Pamphylia', American Journal of Archaeology 95 (1991), 469-488; J. Russell, 'A Roman Military Diploma from Rough Cilicia', Bönner Jahrbücher 195 (1995), 67-133; G. Laminger-Pescher, 'Römische Soldaten in Isaurien', Festschrift für Artur Betz (Vienna 1985), 381-392.

${ }^{28}$ B.D. Shaw, 'Bandit Highlands and Lowland Peace: the Mountains of Cilicia-Isauria', Journal of the Economic and Social History of the Orient 33 (1990), 199-233; 237-270.

${ }^{29}$ Tacitus, Annales 6.41.

${ }^{30}$ 4-3 B.C.: Levick 1967, op. cit. (n.21), 203-214; 43-48: Année Epigraphique 1953, 251 = A.E. Gordon, Q. Veranius, Consul A.D. 49 (Berkeley 1952); Dio 60.8.2; 52: Tacitus, Annales 12.55.

${ }^{31}$ Contra Mitchell 1993, op. cit. (n.15), 1, 122-123 and M. Waelkens, 'The Adoption of Roman Building Techniques in the Architecture of Asia Minor', in Macready \& Thompson 1987, op. cit. (n.2), 94-105 at 99 and 102.

${ }^{32}$ P. Middleton, 'Army Supply in Roman Gaul', in B.C. Burnham \& H.B. Johnson, eds., Invasion and Response (Oxford 1979), 81-98; Idem, 'The Roman Army and Long Distance Trade', in P. Garnsey \& C.R. Whittaker, eds., Trade and Famine in Classical Antiquity (Cambridge 1983), 75-83; Millett 1990, op. cit. (n.6).
} 
the arrival of the Roman imperial cult. ${ }^{33}$ At Cestrus, a temple of the imperial cult was dedicated to Vespasian in 76, which included statues of Vespasian, Titus and probably Domitian. ${ }^{34}$ This is also true of Lamus (modern Adanda), where the temple was dedicated to Vespasian and Titus by the governor Lucius Octavius Memor in $77 .^{35}$ Both Cestrus and Lamus were small, poor and obscure cities. The speed of dedication in both cities suggest that the organisation of their cults and construction of their temples began very soon after 72. Besides Cestrus and Lamus, other temples of the imperial cult are known from Iotape, Laertes, Claudiopolis and Selinus, as well as a possible example from Antiochia ad Cragum. ${ }^{36}$

Erecting a temple for the imperial cult was a political act, one that would not have taken place without Roman imperial control. ${ }^{37}$ The economic consequences of this political act are considerable. Building a temple required stone and timber, workmen and an architect. The skills required for cutting stone into blocks and building simple structures were available everywhere in the region. Architects were needed for design and specialists for any detailed carving, as well as for statuary and for mosaics. ${ }^{38}$ A number of inscriptions from the region mention the work of professional craftsmen (technitai). Their work is usually ornate; if a tomb, then it is often decorated with busts or wreaths, as at Direvli, a village c. $5 \mathrm{~km}$ to the north-east of Lamus, where Kendeas and Kallimachus, craftsmen from Selge, built four tombs, three decorated with busts. ${ }^{39}$ Selge lies c. $150 \mathrm{~km}$ to the north-west and may have had a minor school of sculpture. Two brothers, Attalus and Mene[as], sons of Attalus, built a tomb at Lamus. They came from $\Sigma \varepsilon \lambda . .$. , but the presence of other Selgians doing high quality work at Direvli suggests it was Selge, not the closer Selinus. ${ }^{40}$ Some of these men travelled

33 S.R.F. Price, Rituals and Power (Cambridge 1984); T.B. Mitford, 'The Cults of Roman Rough Cilicia', $A N R W$ II 18,3 (Berlin 1990), 2131-2160 at 2152-2155; cf. IGRR 3, 137 for rapid arrival in Galatia.

${ }^{34}$ G.E. Bean \& T.B. Mitford, Journeys in Rough Cilicia, 1964-1968. Österreichische Akademie der Wissenschaften, Denkschriften 102 (Vienna 1970), 155-160.

${ }^{35}$ B. Sőgüt, 'Lamos'da bulunan bir tapınak', Olba 2 (1999), 399-409; L. Robert, Documents de l'Asie Mineure méridionale (Paris 1966), 72 n.4.

${ }^{36}$ Mitford 1990, op. cit. (n.33), 272-273.

${ }^{37}$ Price 1984, op. cit. (n.33), 69-71; but cf. the possible case of Vologesias, R. Mouterde, 'La voie antique des caravanes', Syria 12 (1931), 105-115 = SEG 7, 135; the reading does depend on a restoration

${ }^{38} \mathrm{Cf}$. further north, M. Sahin, 'Grabdenkmäler aus Isaurien und ihre Künstler', Epigraphica Anatolica 29 (1987), 75-82; J.-P. Adam, Roman Building Techniques (London 1994).

${ }^{39}$ Bean and Mitford 1970, op. cit. (n.34), \#196, 197a, 198, 200.

${ }^{40}$ On Attalus and Meneas, see G.E. Bean \& T.B. Mitford, Journeys in Rough Cilicia in 1962 and 1963. Österreichische Akademie der Wissenschaften, Denkschriften 95 (Vienna 1965), \#34; photos, R. 
in the region. The Selgian Rodōn, son of Kudimasos, built at least one tomb at Direvli where he was also head of a burial club. Since the name is very rare (only one other example is attested in Cilicia and two in eastern Pamphylia), he is probably the same Rodōn who carried out stone work for a certain Apollophanes at Selinus, less than $25 \mathrm{~km}$ from Direvli; this was a statue base of white marble, i.e. an expensive commission. ${ }^{41}$ These are the sort of men who probably worked on temples.

Temple construction had to be paid for in some fashion, whether directly in cash or indirectly by gifts, services, or favours. Construction at some regional temples was boasted about by the patrons and was presumably similar to the process at temples of the imperial cult. About three $\mathrm{km}$ south of Cestrus, at a small coastal temple of Zeus, Neon son of Ingeis recorded his donation of four fluted columns, an iron door, a statue, three craters and a sprinkler. ${ }^{42}$ Further east, in the reign of Antoninus Pius, Dionysodorus of Seleucia bought a priesthood in the village of Tagae. He then paid for the gilding, a marble statue of Athene overlaid with gold, as well as the doors and a rock-cut staircase to the temple. ${ }^{43}$ Once built, maintenance was required, and most temples had estates attached to provide revenues. Temples also required priests who were often commemorated in lists inscribed on the exterior wall of the temple sanctuary, as at Hamaxia, Corycus and Diocaesarea. ${ }^{44}$

The priests of the imperial cult carried out many activities involving considerable expenditure, especially on vestments and crowns. ${ }^{45}$ Most common were sacrifices. It is hard to be certain about the frequency of celebrations, but they probably occurred several times a month. ${ }^{46}$ The wine, incense and animals used for these were available locally, but a recurring demand was created for these consumable items, which had not existed

Paribeni \& P. Romanelli, 'Studi e ricerche archeologiche nell' Anatolia meridionale', Monumenti Antichi 23 (1915), 5-277, figs. 35-37 at 156-158.

${ }^{41}$ Direvli, Bean and Mitford 1970, op. cit. (n.34), \#199, 201; Selinus, \#156 and p. 154.

${ }^{42}$ G.E Bean \& T.B. Mitford, 'Sites Old and New in Rough Cilicia', Anatolian Studies 12 (1962), 185217, \#35; Paribeni and Romanelli 1915, op. cit. (n.40), 150.

${ }^{43}$ L. Robert, Hellenica 3 (1946), 163-167; J. Keil \& A. Wilhelm, 'Vorläufiger Bericht über eine Reise in Kilikien', Jahrbuch des Österreichischen archäologischen Instituts in Wien 18 (1915), 6-60 at 2332.

${ }^{44}$ E.L. Hicks, 'Inscriptions from Western Cilicia', Journal of Hellenic Studies 12 (1891), 225-273, \#27-\#28, list of priests; Heberdey \& Wilhelm 1896, op. cit. (n.22), 71-79, and possibly also \#156.

${ }^{45}$ Price 1984, op. cit. (n.33), 170-171; cf. Britain: Tacitus, Annales 14.31 and C.J. Simpson, 'Once Again Claudius and the Temple at Colchester', Britannia 24 (1993), 1-6.

${ }^{46}$ D. Fishwick, 'Dated inscriptions and the Feriale Duranum', Syria 65 (1988), 349-361; cf. J. Rives, Religion and Authority in Roman Carthage (Oxford 1995), 59-60. 
before. Other celebrations paid for by imperial priests included feasts, athletic competitions, gladiatorial events and animal hunts. Although athletic competitions and feasts were traditional, animal hunts and gladiatorial events were only celebrated as part of the imperial cult. ${ }^{47}$ After 72 , an additional venue for competition came with the establishment of an independent Koinon of the Cilicians whose quadrennial games were usually held at Tarsus. Previously, Cilician cities had competed in Antioch with Syrians and Phoenicians. $^{48}$

The second area where the imposition of direct Roman rule had a major economic impact was in the communication network, i.e. the construction and maintenance of roads and support for the cursus publicus (map). Because of the mountains, there were no major communication routes in Rough Cilicia; the major pass through the Taurus was at the Cilician Gates, some distance to the east. Within Rough Cilicia itself, there was a route between Iconium and Seleucia, a minor coastal road linking the coastal cities and some roads between inland cities and the coast. Work on the main route started very soon after the imposition of Roman direct rule. A road from Diocaesarea to Olba was worked on in 75-76, a bridge over the Calycadnus at Seleucia was completed in 77 by Lucius Octavius Memor, while work on the road from Seleucia to Claudiopolis is recorded in $80 .{ }^{49}$ The coastal road was worked on in Hadrian's reign. ${ }^{50}$ Work is also known on some of the roads which ran inland from the coast, e.g. from Anemurium to Germanicopolis. $^{51}$

All of these routes existed before, but as muddy tracks rather than state maintained roads. Looking after the roads was a major task. Local temperatures varied enormously, from below freezing in winter to over $40^{\circ}$ $\mathrm{C}$ in summer. Torrential rain and rockslides in the mountains added to the difficulties. Building and maintaining these roads fell, for the most part, on local communities. With the state co-opting labour, draft animals and raw

\footnotetext{
${ }^{47}$ Price 1984, op. cit. (n.33), 89; 101-132; L. Robert, Les gladiateurs dans l'Orient grec (Paris 1940), 240; 267-275; cf. Motas, a gladiator buried at Antiochia-ad-Cragum, IGRR 3, 837.

${ }^{48}$ R. Ziegler, Städtisches Prestige und kaiserliche Politik: Studien zum Festwesen in Ostkilikien im 2. und 3. Jahrhundert n. Chr. (Düsseldorf 1985), 58-66; Mitchell 1993, op. cit. (n.15), 1, 217-225; R. Ziegler, 'Studien zum antiken Kleinasien 3', Asia Minor Studien 16 (1995), 183-186.

49 T.S. Mackay \& P.A. Mackay, 'Inscriptions from rough Cilicia east of the Calycadnus', Anatolian Studies 19 (1969), 139-142; IGRR 3, 840; M.H. Sayar, 'Strassenbau in Kilikien unter den Flaviern nach einem neugefundenen Meilenstein', Epigraphica Anatolica 20 (1992), 57-62.

${ }^{50}$ Bean \& Mitford 1962, op. cit. (n.42), \#46 at Charadrus.

${ }^{51}$ Bean \& Mitford 1965, op. cit. (n.40), \#210
} 
materials easily available from the mountains, there were few other costs. ${ }^{52}$ This process of road construction and maintenance would have been enormously expensive if paid for in cash. But it was paid for in political capital. The ramifications were felt in every town and village on the way.

Along with the roads came the cursus publicus and its requirement to provide draft animals and wagons. The requirements were related to state needs, so in Rough Cilicia would probably have been on the same scale (if not smaller) as the Pisidian mountain city of Sagalassus, where the requirement was to have 10 carts and mules available. The requirements were tied to a city's territory, but could be drawn from every community within it, so could have affected every village. ${ }^{53}$

The imperial cult and communications were the major areas of Roman impact in Rough Cilicia. Although there were other possible impacts, these did not occur in Rough Cilicia. Thus, in other areas of Asia Minor, some types of construction have been particularly associated with the arrival of Roman rule, e.g. bath-buildings, aqueducts, amphitheatres and monumental arches. ${ }^{54}$ In many cases, the empire sponsored their construction. ${ }^{55}$ But in Rough Cilicia, though these structures existed, there is no evidence of imperial grants for their building, so they are better thought of as evidence for cultural rather than political impact. Nor did the coinage used in the region change much with the imposition of direct rule. Under Antiochus IV, coins were minted at Selinus, Cietis, Anemurium, Celenderis, Corycus and Elaeussa, while Olba also issued its own coinage. ${ }^{56}$ After 72 , coinage acknowledging the new rulers was only introduced slowly. Olba issued coins acknowledging Vespasian, and Anemurium struck for Titus, but it was not until Domitian that coins were issued by other cities, Titiopolis, Celenderis, Coropissus and Diocaesarea. ${ }^{57}$ Economically, the region had always depended on coins minted elsewhere and continued to do so.

The methodological stance taken here starts from the Roman state itself, a complex network of political relationships built up incrementally over

\footnotetext{
${ }^{52}$ Mitchell 1993, op. cit. (n.15), 1, 124-132, esp. 126-7.

${ }^{53}$ See the article by A. Kolb, in this volume; see S. Mitchell, 'Requisitioned Transport in the Roman Empire: a new inscription from Pisidia', Journal of Roman Studies 66 (1976), 106-131.

54 J.J. Coulton, 'Roman Aqueducts in Asia Minor', in Macready \& Thompson 1987, op. cit. (n.2), 72 84; A. Farrington, The Roman Baths of Lycia (London 1995), 117-144.

${ }^{55} \mathrm{~S}$. Mitchell, 'Imperial Building in the Eastern Roman Provinces', in Macready \& Thompson 1987, op. cit. (n.2), 18-25; Farrington 1995, op. cit (n.54), 128.

${ }^{56}$ A. Burnett, et al., Roman Provincial Coinage 1 (London 1992), 560-566

57 A. Burnett, et al., Roman Provincial Coinage 2 (London 1999), 247-260
} 
time, overlying pre-existing cultures and political units. However, culture and politics cannot be separated. Some of the cultural change in Iron Age Europe was directly driven by the Empire, while some of the imperial activities resulted in economic gain. But in neither case did the empire's impact take a peculiarly economic form. The source material may not tell us everything that we wish to know, but it would look very different if the motives for imperial expansion were primarily or even partially economic, or if the state was concerned about developing the economy (as opposed to collecting taxes). The evidence from Rough Cilicia suggests that, without the army, the changes brought about by the Roman state were small, even if the changes brought about by being culturally Roman were immense.

Ankara, December 2001 